riages to all Jewish marriages has slightly increased, whereas the proportion to all Christian marriages has declined slightly. This is attributable to a decline in the Jewish population and an increase in the Christian after 1919. There is a further tendency to be noted in the fact that a greater number of Christian brides marry Jewish men than of Jewish brides who marry Christian men. Here again there is a marked increase in the differential between the two types in the post-War years.

\section{New World Origins}

For long the amazing efflorescence of indigenous culture among the Mayas and Aztec of Central America was the only aspect of American archæology to attract the serious interests of European students. Even the intensely absorbing question of the origin, character and chronology of such alleged early skeletal remains, germane as it was to the inquiries of human palæontology and ethnic origins in the Old World, received less attention than it deserved. Extravagant claims for the antiquity of man on the American continent, readily demolished in most instances, were no doubt responsible for something more than a certain reserve in the approach to the general question. All this has to a great degree been changed, and the discovery of the Folsom point in New Mexico and other regions of the south-western United States in clear association with an extinct fauna has now placed the discussion of the antiquity of man in America and the early cultural history of the continent on a basis which enables British archæologists to enter upon the discussion of a problem conditioned by data of which they have a ready understanding and with which it may be said they have at present a closer acquaintance than their American colleagues. This is implicitly admitted by Prof. E. B. Renaud, one of the pioneers in the study of Folsom man, in his most recent published work.

The literature of Folsom man is already large ; but to those who have not been able to follow it closely, we may commend an excellent critical analysis which is part of a discussion of the whole question of New World origins appearing in Antiquity of June, by Dr. J. Grahame D. Clark, whose experience of analogous European stone age cultures carries great weight. His typological argument on the much debated question of the relation of the Folsom point and the more generalized Yuma point therefore deserve careful attention, although the recently discovered northward extension of the Folsom point so far as Canada may be found to have greater significance than as yet has been attached to it.

\section{"Elephants and Ethnologists"}

AN echo of the famous "Elephants and Ethnologists" controversy appears in a contribution by Mr. W. Balfour Gourlay in Man of June 1940. This controversy, it will be remembered, turned on the alleged occurrence of representations of the elephant in the Mayan sculptures of Central America, which were held to demonstrate the Asiatic derivation of Central American culture, while others held, as it has been put, that the elephants had trampled finally on the theories of the Diffusionist School of Elliot Smith, Perry and their followers. Mr. Gourlay refers in the first place to a discovery brought to his notice at Guadalajara, Jalisco, in Mexico. Here it was stated human and elephant bones had been found in association. He did not see the find in situ, but his subsequent inquiries leave no doubt that the position of the human bones was due to burial.

A more intriguing evidence was observed by $\mathrm{Mr}$. Gourlay in 1921. It left him in little doubt that man had lived in Central America in contemporary association with some elephant-like creature. This was a primitive and almost life-sized representation of the head of a strange animal carved from a block of black lava which then stood on a pedestal outside the museum at San Salvador. The statue, of which two photographs are shown, was about two feet high. 'The animal bore a trunk, too long for that of a tapir, too short for an elephant. If it was intended to represent an elephant, the artist evidently had never seen one, and did not understand its anatomy, as the eyes were placed in the middle of the ear-lobes. Sir Grafton Elliot Smith, to whom the photographs were shown, was convinced that an elephant was intended, much copying being responsible for the departure from realism; but the author is not convinced and regards it as a problem demanding solution.

\section{Attracting Birds}

IN earlier less sophisticated days the desirability of attracting birds was accepted without question. Now doubts have arisen, partly because it is recognized that some birds may do some harm to man's possessions, and partly because the congregating of birds at a common feeding ground may lead to the spread of diseases among the birds themselves. These dangers are recognized and provided for in a new pamphlet, the first of a series of Conservation Bulletins, issued by the Bureau of Biological Survey of the U.S. Department of the Interior. In it W. L. McAtee summarizes clearly and with line illustrations suitable methods of encouraging nesting, and discusses the proper foods to be supplied to a number of the commoner birds of the States. His hints apply equally well to many British birds, and particularly useful will be found a short section dealing with common cultivated annual plants which may be sown for the encouragement of seed-eaters such as siskins, gold-finches and other finches. For fruit-eating birds there is a short list of shrubs and trees the fruits of which persist into the winter, when the birds have most need of them. It is a useful list for anyone wishing to create a shrubbery likely to be appreciated by winter bird visitors.

\section{Significance of Television}

AN instructive address on television given at Buenos Aires last year by Mr. W. E. Tremain, chairman of the Argentine Centre of the Institution of Electrical Engineers, is published in the May issue of the Journal of the Institution of Electrical Engineers. 
Mr. Tremain begins by saying that the more we study recent developments in television, the more we are forced to realize that high-definition television is one of the outstanding scientific and engineering achievements of our time. In August 1936, the Alexandra Palace transmitter in north London was in full operation, giving the first public television service in the world. On May 12, 1937, the Coronation procession was televized with much success. It was the first outside television exhibition of importance. In conclusion, Mr. Tremain points out that television is destined to play in the future a leading part both as a means of communication and as a means of instruction. When planning for the future, it is important to bear this in mind. In England, as a result of pressure both from the cinema and radio industries, the experimental work being conducted for the purpose of extending the television service in the provinces was expedited. If a definite decision be taken with this end in view, we can look forward hopefully to it giving much direct employment in happier times.

\section{Standardizing Electric Distribution Cables}

Mr. S. W. Mexsom, of the staff of the Cable Makers' Association, has contributed a paper on the standardization of cables and equipment, with the object of reducing distribution costs, to the Electrical Review of June 7. Discussions have been going on for several years in order to frame an acceptable set of rules. The outbreak of war prevented the embodiment in the revised British Standard Specification for mains cables of the discussions during the last two or three years. The selection of standard sizes for cables to be used in a low-voltage network is a matter almost entirely for the supply engineers. It is difficult to forecast accurately the load which a distributor will have to carry, and since the data on which estimation has to be based are somewhat nebulous, there are strong reasons for the adoption of a few-possibly not more than two-standard sizes for a given system of low-voltage four-core cables.

Since the size of the undertaking and the loaddensity in the cable must vary between districts, it has been suggested that three sizes of four-core cable are required, namely, $0 \cdot 1,0.2$ and $0.3 \mathrm{sq}$. in., the smaller sizes being sufficient for the smaller systems and the larger for larger systems. Some suggest also that it would be more economical to use shaped and not circular conductors. The initial difficulties experienced in the construction of this type of cable have been overcome by the use of special apparatus. It is believed that the shaped conductor is quite as satisfactory as a circular conductor and is better technically. Difficulties have been experienced as to the best colours to use to identify the cores. The proposals that have been put forward envisage leaving the colours to the switchboard manufacturers and using numbers for the identification of cable cores. The questions of factor of safety and cost, now nearing solution, have involved a very large amount of work on the part of designers, research laboratories and testing authorities and great improvements are in immediate prospect.

\section{An Automatic Distress Signal}

THE Ministry of Shipping has given its approval to the 'Raft-o-Lite' safety flashing light of the International Marine Radio Co., Ltd., 63 Aldwych, W.C.2. It comprises a battery and light in a watertight case, provided with a float so that it will assume a vertical position when floating in the sea. A flasher is incorporated with it and this is designed to emit automatically the international distress signal 'S.O.S.'. When stored in an inverted or horizontal position the light is not in use, but when thrown into the water it assumes a vertical position and the flashing light is automatically switched on, continuing for forty-eight hours at least. The manufacturers point out that these lights are particularly suitable for oil-burning ships and tankers, where oil on the water may render dangerous the use of open flares.

\section{Breeding of Herbage Plants in Scandinavia and Finland}

Joint Publication No. 3, "The Breeding of Herbage Plants in Scandinavia and Finland" of the Imperial Agricultural Bureaux of Aberystwyth and Cambridge contains considerable information on the breeding of clovers and pasture grasses in Norway, Sweden, Denmark and Finland. The contributors are S. Nilsson-Leissner, F. Nilsson, E. Akerberg, R. Torssell, H. N. Frandsen, H. Wexelsen, and $O$. Pokjakalliv. A significant feature of the work in these countries is that the breeding work on a given crop has led to the country becoming independent of foreign seed for that crop. It was found, for example, that selection of late strains of red clover from local strains improved the yield by 10 per cent, and such selections are now so popular in Denmark that it is unnecessary to import seed. Similar results are reported from Norway and Sweden, where resistance to Sclerotinia trifoliorum and 'Tylenchus, 'persistance' and winter hardiness are of particular importance.

Both in red clover and timothy grass, inbreeding has been found to lead to drop in yield, vigour and fertility, while the 'hybrid corn method' of crossing inbred lines to produce heterosis is scarcely practicable. It is found preferable to adopt plant selection and cross breeding to give natural selection full scope. Frost hardiness is selected for by removing the snow from timothy plants. Alsike and white clover together with various species of Lolium, Festuca, Poa, Agrostis, Dactylis, Bromus and other genera are being bred for commercial work. The more important varieties which have been raised and a list of the many plantbreeding stations in Scandinavia which are given in this useful publication indicate the extent of the work in progress.

\section{Map of Antarctica}

THE Antaretic regions have been of official interest to Australia since 1933, when the Commonwealth Government announced its claim to a large sector of the continent south of the Indian Ocean between the Ross Dependency of New Zealand and Enderby Land. The Australian Antarctic Territory embraces about one quarter of the Antarctic regions. The 